\title{
Connection Between Body Position During Sleep and Findings from Full- Night Polysomnography in Patients with Obstructive Sleep Apnea
}

\author{
Alen Juginović $c^{1,2}$ (D), Renata Pecotić ${ }^{1}$ \\ University of Split School of Medicine, Split, Croatia \\ St. Catherine Specialty Hospital, Zabok, Croatia
}

ABSTRACT:

Aim: The aim of our study was to determine the association between body position during sleep and OSA severity in patients with newly diagnosed OSA after full-length polysomnography.

Subjects and Methods: We conducted a cross-sectional and clinical study involving 414 subjects (281 men and 133 women) older than 18 whose median age was 55 years. In 2017, subjects came to the Center for Sleep Medicine at UHC Split and the Split School of Medicine and their dana was taken from the archives of the same center. All patients did a full-night polysomnography after which the severity of OSA was estimated with the help of AHI in accordance with the OSA diagnosis guidelines prescribed by the American Academy of Sleep Medicine (AASM) and European Sleep Research Society (ESRS). Excessive daily sleepiness has been estimated by the Epworth Sleepiness Scale (ESS). Results: Statistical analysis showed that patients had spent more time on the back $(189.9 \pm 118.4 \mathrm{~min})$ than on the left $(113.3 \pm 90.9 \mathrm{~min})$ or right side $(80.6 \pm 90.6 \mathrm{~min})$ during sleep and had the most sleep apneas on their back $(\mathrm{AHI}=31.1 \pm 31.9)$. Patients with diagnosed OSA $(\mathrm{AHI} \geq 5)$ also had higher AHI values on the back $(39.1 \pm 31.9)$ than on the left $(23.8 \pm 25.2)$ or right side $(18.5 \pm 25.6)$ during sleep. Patients with diagnosed OSA in comparison to patients without OSA diagnosis had statistically significantly higher BMI $(29.5 \pm 4.6 \mathrm{~kg} / \mathrm{m} 2$ vs. $25.3 \pm 4.1 \mathrm{~kg} / \mathrm{m} 2, \mathrm{P}<0.001)$ and neck circumference $(42.0 \pm 4.4 \mathrm{~cm}$ vs $37.4 \pm 3.9 \mathrm{~cm}, \mathrm{P}<0.001)$. Overall, considering the whole sample, men were taller $(180.8 \pm 7.4 \mathrm{~cm}$ than $165.9 \pm 6.7 \mathrm{~cm}, \mathrm{P}<0.001)$, had higher BMI $(29.4 \pm 4.5 \mathrm{~kg} / \mathrm{m} 2$ compared to $26.8 \pm 4.9 \mathrm{~kg} / \mathrm{m} 2, \mathrm{P}<0.001)$ and bigger neck circumference $(43.2 \pm 3.5 \mathrm{~cm}$ vs. $36.2 \pm 3.4 \mathrm{~cm}, \mathrm{P}=0.002)$, as well as a larger ESS sum $(7.6 \pm 4.7$ compared to $6.3 \pm 4.8, \mathrm{P}=0.021)$. Using the Pearson Correlation Coefficient, we showed a negative correlation of AHI with sleep time on the right side $(\mathrm{r}=-0.178$, $\mathrm{P}=0.005)$ in OSA patients, while positive correlation was found in sleep on the left side $(\mathrm{r}=0.003, \mathrm{P}=0.959)$ and back $(r=0.183, \mathrm{P}=0.002)$. Conclusion: Our research showed that patients sleep the most time $\mathrm{n}$ their back and that

OPEN ACCESS

Correspondence:

Alen Juginović MD alen.juginovic27@gmail.com orcid.org/0000-0003-4871-1963

This article was submitted to RAD CASA - Medical Sciences as the original article

Conflict of Interest Statement: The authors declare that the research was conducted in the absence of any commercial or financial relationships that could be construed as a potential conflict of

interest.

Received: 17 July 2019 Accepted: 1 December 2019 Published: 17 December 2019

Citation:

Juginović A, Pecotić R. Connection Between Body Position During Sleep and Findings from Full-Night Polysomnography in Patients with Obstructive Sleep Apnea. RAD CASA - Medical Sciences. $540=48$ 49 (2019): 15-26. https://dx.doi. org/10.21857/ydkx2crgw9

Copyright (C) 2019 Juginović and Pecotić. This is an open-access article distributed under the terms

of the Creative Commons Attribution License (CC BY). The use, distribution or reproduction in other forums is permitted, provided the original author(s) and the copyright owners(s) are credited and that the original publication in this journal is cited, in accordance whit accepted adacemic practice. No use, distribution or reproduction is permitted which does not comply with these $\mathrm{AHI}$ ist the highest in that sleep position in comparison to other sleep position which worsens sleep quality in the long term.

KEYWORDS: Sleep; Body position; Polysomnography; Obstrucitve Sleep Apnea

\section{SAŽETAK:}

POVEZANOST POLOŽAJA TIJELA TIJEKOM SPAVANJA S NALAZIMA CJELONOĆNE POLISOMNOGRAFIJE U PACIJENATA $S$ OPSTRUKCIJSKOM APNEJOM

Cilj: Cilj našeg istraživanja je utvrditi povezanost položaja tijela tijekom spavanja sa stupnjem OSA-e u pacijenata $s$ novodijagnosticiranom OSA-om nakon cjelonoćne polisomnografije.

Ispitanici i metode: Proveli smo presječno i kliničko istraživanje koje je uključivalo 414 ispitanika (281 muškarac i 133 žene) starijih od 18 godina čiji je medijan starosti bio 55 godina. Ispitanici su 2017. godine došli na dijagnostičku obradu u Centar za medicinu spavanja KBC-a Split i Medicinskog fakulteta u Splitu te su njihovi podatci uzeti iz arhive istog centra. Svim pacijentima napravljena je cjelonoćna polisomnografija nakon koje je s pomoću AHI-ja procijenjena težina OSA-e u skladu sa smjernicama za dijagnostiku OSA-e koje su propisane od strane Američke akademije za medicinu spavanja (engl. American Academy of Sleep Medicine, AASM) i Europskog društva za istraživanje spavanja (engl. European Sleep Research Society, ESRS). Prekomjerna dnevna pospanost procijenjena je Epworthovom ljestvicom pospanosti (engl. Epworth Sleepiness Scale, ESS). Rezultati: Statistička

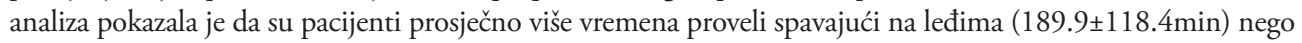
na lijevom $(113.3 \pm 90.9 \mathrm{~min})$ ili desnom boku $(80.6 \pm 90.6 \mathrm{~min})$ te da su imali najviše apneja tijekom spavanja na leđima (AHI=31.1 \pm 31.9$)$. Pacijenti s dijagnosticiranom OSA-om $(\mathrm{AHI} \geq 5)$ također su imali veću AHI vrijednost na leđima (39.1 \pm 31.9$)$ nego na lijevom $(23.8 \pm 25.2)$ ili desnom boku (18.5 \pm 25.6$)$. Pacijenti $s$ dijagnosticiranom OSA-om u odnosu na pacijente bez dijagnoze OSA-e imali su statistički značajno veći ITM $(29.5 \pm 4.6 \mathrm{~kg} / \mathrm{m} 2 \mathrm{vs}$ $25.3 \pm 4.1 \mathrm{~kg} / \mathrm{m} 2, \mathrm{P}<0.001)$ i opseg vrata $(42.0 \pm 4.4 \mathrm{~cm}$ vs $37.4 \pm 3.9 \mathrm{~cm}, \mathrm{P}<0.001)$. Ukupno gledajući cijeli uzorak, muškarci su bili viši $(180.8 \pm 7.4 \mathrm{~cm}$ u odnosu na $165.9 \pm 6.7 \mathrm{~cm}, P<0.001)$, imali veći ITM $(29.4 \pm 4.5 \mathrm{~kg} / \mathrm{m} 2 \mathrm{u}$ odnosu na $26.8 \pm 4.9 \mathrm{~kg} / \mathrm{m} 2, \mathrm{P}<0.001)$ i opseg vrata $(43.2 \pm 3.5 \mathrm{~cm}$ u odnosu na $36.2 \pm 3.4 \mathrm{~cm}, \mathrm{P}=0.002)$, kao i veći ESS zbroj (7.6 \pm 4.7 u odnosu na 6.3 $\pm 4.8, P=0.021)$. Koristeći Pearsonov koeficijent korelacije, uočili smo negativnu korelaciju AHI-ja s vremenom spavanja na desnom boku $(\mathrm{r}=-0.178, \mathrm{P}=0.005)$ u pacijenata s OSA-om, dok je pozitivna korelacija pronađena kod spavanja ne lijevom boku $(r=0.003, P=0.959)$ i leđima $(r=0.183, P=0.002)$. Zaključak: Naše istraživanje pokazalo je da pacijenti najviše vremena provode spavajući na leđima te da je AHI vrijednost upravo u tom položaju veća u odnosu na druge položaje tijela što dugoročno narušava kvalitetu spavanja.

KLJUČnE RIJEČI: Spavanje; Položaj tijela; Polisomnografija; Opstruktivna apneja 


\section{What is SLeep?}

Up until the 1950s, many people thought of sleep as a passive part of our life although we spend almost a third of our life sleeping. Today we know for sure that our brain is very active during sleep and that some of its parts are even more active than when awake. Though not easy to define it, sleep is considered a natural state of altered counciousness which is characterized by relative inhibition of sensory activity, inhibition of almost all voluntary (skeletal, striated) muscles and reduced interaction with the environment ${ }^{1}$. The optimal number of hours of sleep ranges from 7 to 9 for people between 18 and 65 years of age. For older people the optimal number of hours of sleep is a bit less, for younger ones a bit more, while babies under the age of 1 need 12 to 17 hours (Figure 1) ${ }^{2,3}$. For good sleep quality, sleep hygiene is very important. It includes various habits or exercises that not only assure a comfortable night, but high concetration and apention levels during the day. Some parts of good sleep hygiene are:

- No caffeine, alcohol or other stimuli right before sleep

- No fapy/heavy food right before sleep

- Active lifestyle during the day

- Sleeping on a quality mapress and pillow in a dark envi ronment with adequate and comfortable room temperature - Consistent rhythm and hours of sleep in regards to age

- No usage of computers, smartphones and other electronic devices before sleep that emit blue light etc.

Sleep can be split into two phases which interchange, non-REM (non-Rapid Eye Movement) and REM (Rapid Eye Movement) phase. Non-REM phase consists of three sleep stages (stage N1, N2, and N3), while REM phase includes only REM sleep stage. During sleep, most people go through several (4-5) cycles of sleep (Figure 2), depending on how much time they sleep. One sleep cycle lasts roughly 90 to 110 minutes and is defined as a period in which a person goes through the aforementioned stages of non-REM and REM sleep. Most healthy adults begin their sleep cycle in stage N1 right after they fall asleep. Next, they go into stage N2 which is the longest sleep stage, then to stage $\mathrm{N} 3$ and afterwards back to one of the shallower stages like stage N1 or N2. The last stage is REM sleep stage which concludes the sleep cycle. A new cycle begins after the person goes into stage $\mathrm{N} 1$ or $\mathrm{N} 2$ after they leave the REM sleep stage in the previous sleep cycle and then the classic papern continues: stage $\mathrm{N} 1$ - stage N2 - stage N3 - stage N1 or N2 - REM stage - new sleep cycle. Interestingly, mammals (dogs, cats etc.) have been found to have a very similar fundamental sleep cycle to humans ${ }^{5}$.

\section{The Circadian Rhythm}

Circadian rhythm (Latin "circa" = around; Latin "diem" = day) is an endogenous cyclic rhythm with a periodicity of around 24 hours which regulates the sleep/wake cycle. This rhythm is controled by the circadian or biological or circadian clock ${ }^{1}$. It is extremely important because many biochemical and physiological processes depend on it functioning well. A branch in biology which studies periodic phenomena in living beings is called chronobiology (Greek "chronos" = time). In 2017, The Nobel Prize in Physiology or Medicine was awarded to three scientists from the USA for discovering the molecular mechanisms controlling the circadian rhythm of the fruit $\mathrm{Al}^{6,7}$.

Almost 300 years ago, De Mairan proved the existence of an endogenous rhythm in plants by studying the folding of leaves of a specific plant in the evening hours. He noticed that the plant was folding its leaves in the evening even when it was kept constantly in the dark the whole day. He described this as though "the plant felt the presence of the sun without seeing it ${ }^{\text {"8 }}$. From seaweed to mammals, almost all animals adjusted their circadian clock to the 24 hour cycle which strongly depends on the presence of light.

In humans, the central circadian clock (circadian pacemaker, master clock) in located in the hypothalamus, i.e. in its suprachiasmatic nucleus (Latin "nucleus suprachiasmaticus", SCN) which is located, as the name suggests, above the optic chiasm.

The function of the circadian clock depends a lot on the day/night cycle. Light (not only daylight, but also light emitted from screens of smartphones, TVs, computers etc.) is, along with drugs, temperature, physical activity and other, one of the examples of so called "zeitge-

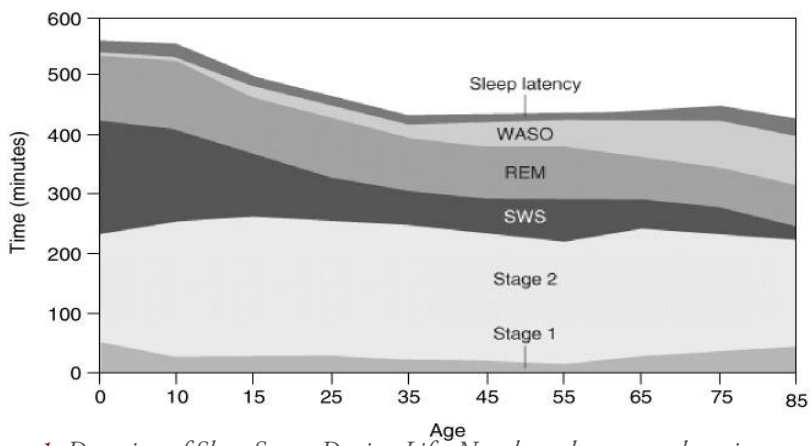

Figure 1. Duration of Sleep Stages During Life. Note how slow-wave sleep, i.e. deep sleep reduces in time as people get older. Furthermore, older people sleep up to $36 \%$ less than 5 -year-old children ${ }^{4}$.

ber" (German for "time giver"), i.e. external factors which affect the circadian clock. Light enters the eye through the pupil and falls on the retina which is made up of 10 histological layers. After the activation of the first-order neurons (photoreceptors: rods, cones) of the visual pathway, the signals go to the bipolar (second-order neurons) and ganglion cells (third-order neurons) whose axons make up the optic nerve. They end up in the thalamic lateral geniculate body

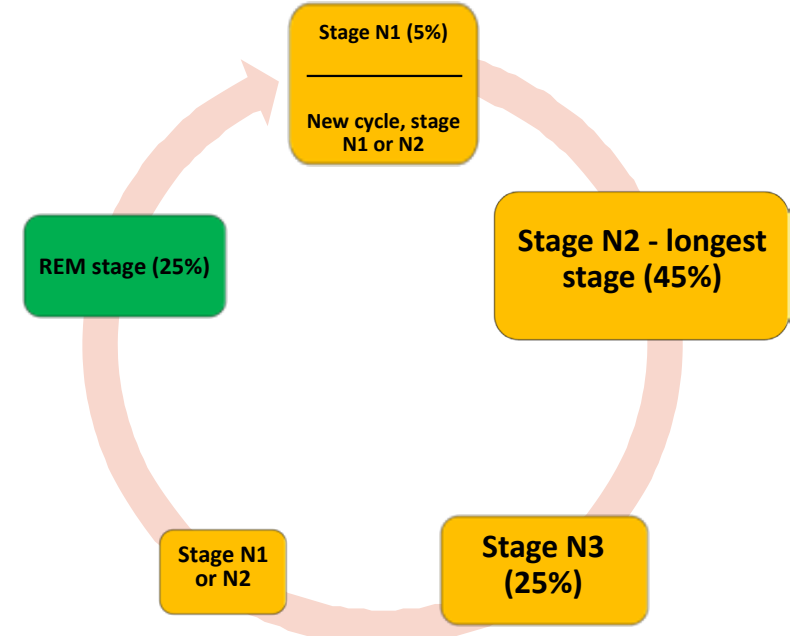

Figure 2. Healthy Adult Sleep Cycle-orange rectangles represent non-REM phase, green REM phase. The percentage in the brackets represents the share of each sleep stage in optimal total sleep time. After stage N3, the induvidual goes shortly to stage N1 or N2 before going to REM. After REM stage, a new sleep cycle begins with either stage N1 or stage N2. 
(fourth-order neuron) and from there the signals go to the cortex of the occipital brain lobe where the picture gets to the conscious level. For the circadian clock, though, first-order neurons are important. Apart from rods (night sight) and cones (colour differentiation), a new small population of cells has been discovered in the retina. These cells called intrinsically photosensitive Retinal Ganglion Cells (ipRGCs) are also photoreceptors. IpRGCs contain light-sensitive photopigment melanopsin which is responsible for their photosensitivity?. When exposed to light for longer and because of melanopsin activation, calcium ions enter the ipRCGs and activate them via membrane depolarization through various physiological processes ${ }^{10}$. The formed electrical impulse (action potential) travels through the axons of ipRGCs directly via the optic nerve right to the hypothalamic suprachiasmatic nucleus (SCN) which is activated by the release of glutamate from the nerve endings. SCN then "knows" that there is light in the environment and "concludes" it is day outside. Remember, the light which activates the ipRGCs can be from computers, smartphones, home lighting etc. and not only sunlight. This is how we can easily deregulate during night the SCN and many physiological processes this nucleus controls in the body. The pathway that connects the ipRGCs to the SCN is called retinohypothalamic pathway because it connects the ipRGCs in the retina to the SCN in the hypothalamus. It is key in the regulation of the circadian clock and therefore the circadian rhythm ${ }^{11}$.

Along with the central circadian clock in the SCN, there are peripheral circadian clocks in various organs (heart, lungs, liver) and systems (endocrine) which the SCN controls, along with the physiological processes.

\section{Breathing Related Sleep Disorders: Sleep Apnea}

Sleep apnea is the most common breathing related sleep disorders and one of the most common sleep disorders in general. It is defined as a total cessation of breathing during sleep which lasts at least 10 seconds and is accompanied by desaturation of at least $3 \%$. Cessation of breathing that does not meet these criteria is not classified as sleep apnea. Sleep apnea can be divided in three groups: obstructive apnea (most common), central apnea and mixed apnea. Another significant clinical entitiy is hypopnea, i.e. shallow breathing. It is defined as a reduction in breathing depht by $30 \%$ compared to normal breathing and lasts at least 10 seconds, usually accompanied by desaturation of $3 \%$ or more.

\section{Risk Factors and Prevalence}

Obstructive sleep apnea represents a major public health issue. According to a 2017 study, the prevalence of sleep apnea in the general population varies from $9 \%$ to as much as $38 \%$ and mostly affects middle aged and older men and significantly less women and children ${ }^{12}$. The most common type of sleep apnea by far is obstructive sleep apnea, followed by mixed and then central apnea. In the United States, at least 25 million adults suffer from sleep apnea, and the number is constantly rising ${ }^{13}$. Risk factors for sleep apnea include: body mass index above 25, narrowed airway, broad neck ( $>43 \mathrm{~cm}$ for men, $>38 \mathrm{~cm}$ for women), male sex, age ( $>40$ years), family history of sleep apnea, alcohol, smoking, intake of sedatives, nasal septum deviation, nasal congestion, stroke (for central apnea). Because of all the risk factors, it is important that people have an active and healthy lifestyle in order to reduce the risk of getting sleep apnea, as well as many other diseases ${ }^{14}$.

\section{Types and Symptoms of Sleep Apnea}

Sleep apnea is divided in three types: obstructive (most common), central and mixed apnea. It is important to remember that all three types share the same basic traits: total cessation of breathing for at least 10 seconds and desaturation of at least 3\%. Obstructive sleep apnea (OSA) is a repetitive breathing cessation during sleep which is caused by partial or complete collapse of the upper airway which blocks or significantly reduces the airflow to the lungs. Primarily, the collapse happens at the level of velopharynx (from the beginning of the soft palate to the uvula) and oropharynx (from the tip of the uvula to the top of the epiglottis). The affected person tries to breathe with thoracic (intercostal muscles) and/or abdominal muscles (diaphragm) but cannot because of the airway obstruction. Causes of the collapse are not yet clarified, but neuromuscular factors probably play a role. Significantly reduced muscle tone of muscles important for maintaining the stability of the upper airway (tensor veli palatini and genioglossus muscles) is an important cause ${ }^{15}$. Muscle tone in normally lower during sleep, but here it is exaggerated. In overweight people, peripharyngeal fat tissue narrows the airway are increases the risk of its collapse, therefore inducing sleep apnea ${ }^{16,17}$. The most common mechanical obstacle to airflow when lying flat is when the base of the tongue falls backwards, thus covering the airway. This can happen together with the collapse of the soft palate and other nearby muscles which alltogether block the airway (Figure 3). Significantly reduced muscle tone (muscle hypotonia) which occurs during sleep and causes the pharyngeal and soft pallet muscle collapse plays a big role in preventing air going to the lungs. In children, enlarged tonsils and/or adenoids (lymphoid tissue) can cause OSA. If so, they can be surgically removed with good outcomes.

The main difference between central sleep apnea (CSA) and obstructive sleep apnea is that in CSA signals from the respiratory centers in the medulla are not reaching the respiratory muscles and the patient in not even trying to breathe because of that. Central apnea is rare, and its causes are not yet fully understood. There are two subtypes of CSA: primary (idiopathic) and secondary. Primary, i.e. idiopathic CSA is of unknown cause, rare and is diagnosed by excluding other potential causes. Secondary CSA can be associated with CheyneStokes respiration, opioid consumption, CSA on high altitude and CSA as a secondary manifestation of certain diseases ${ }^{18}$.

Secondary, CSA may be caused by some neurological disorders including neuromuscular diseases which either significantly weaken or disable breathing due to weakening of the respiratory muscles in one of the phases of the diesase. Some examples are myasthenia gravis, amyotrophic lateral sclerosis (ALS) and others. Due to the inability to breathe, hypercapnia (elevated levels of CO2 in the blood) occurs. Tumors and other lesions in the brainstem can weaken the signal going to the respiratory muscles which is especially noticeable in sleep and can cause hypercapnia.

Secondary CSA also includes the hereditary disease called congenital central hypoventilation syndrome, also known as Ondine's curse. For genetic reasons and without an anatomical and pathological substrate, alveolar hypoventilation occurs during sleep and causes hypercapnia and hypoxemia (20). Primarily central chemoreceptors in the brainstem react to hypercapnia (peripheral chemoreceptors in the aortic and carotide body react too). They "notice" the change in $\mathrm{pH}$ in the cerebrospinal fluid, i.e. blood which becomes acidic (acidosis). Chemoreceptors react to hypercapnia with hyperventilation to get excess $\mathrm{CO} 2$ out of the blood. People who have "overly sensitive" 


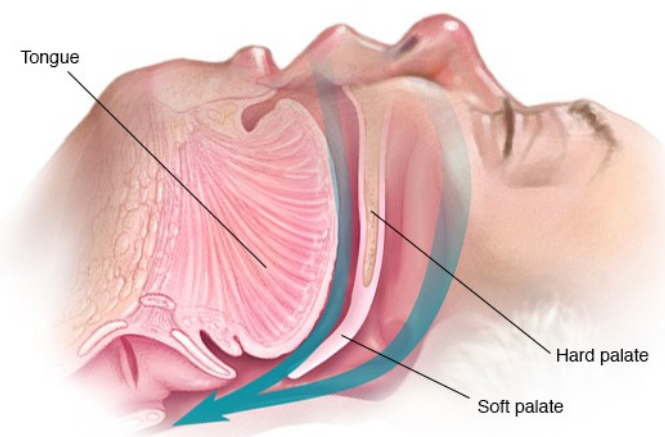

Obstructive sleep apnea

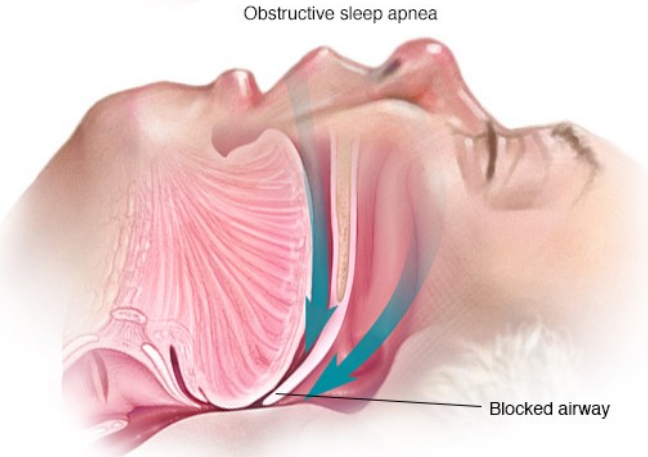

Figure 3. Obstructive Sleep Apnea - soft palate and tongue fall backwards due to significant muscle hypotonia and block the airflow (19).

chemoreceptors or some underlying diseases may exhibit unnecessarily long hyperventilation periods which lead to the reduction of $\mathrm{PaCO}_{2}$ (partial pressure of $\mathrm{CO}_{2}$ in arterial blood) on a level significantly lower than normal, below the so called $\mathrm{CO}_{2}$ apenic threshold and therefore breathing cessation occurs. Reduction of $\mathrm{PaCO}_{2}$ below the $\mathrm{CO}_{2}$ apenic threshold during sleep leads to breathing cessation, i.e. central sleep apnea. In summary, in Ondine's curse, reduction of $\mathrm{PaCO} 2$ due to hyperventilation below the apenic threshold which is located just below the normal level od $\mathrm{CO}_{2}$, leads to hypoventilation and breathing cessation during sleep without breathing muscle contractions, i.e. leads to central sleep apnea ${ }^{20}$.

Central sleep apnea with characteristics of Cheyne-Stokes respiration is described as irregular crescendo/decrescendo breathing which oscilates between hypopnea, hyperpnea and then hypopnea and finally apnea. The person takes shallow breaths followed by deep ones and then shallow ones again up to the point of total breathing cessation (Figure 4).

Cheyne-Stokes respiration cycle lasts $60-90$ seconds $^{22}$. The cause of it lies in the increase of $\mathrm{CO} 2$ in the blood, i.e. hypercapnia which leads to compensation in the form of hyperventilation which leads to hypocapnia and finally apnea to "build up" the reduced CO2. An especially important cause of CSA with Cheyne-Stokes respiration paperns is heart failure in as many as $60 \%$ of cases. Due to prolonged circulatory time in heart failure patients, $\mathrm{CO} 2$ needs more time to reach the central chemoreceptors which causes constant "overshooting" of the adequate CO2 level and more than needed longevity of hyperventilation which leades to hypocapnia and the reduction of $\mathrm{PaCO} 2$ below the $\mathrm{CO} 2$ apneic threshold and the occurrence of central apnea ${ }^{23}$. This type of respiration can be found in renal failure and other neurological disorders.

CSA is connected with long-term opioid use (morphine, heroin, codeine and other) because they suppress breathing by acting on $\mu$-opioid receptor sin the medulla ${ }^{24,25}$. Furthermore, high altitudes, especially above 7600 meters but lower as well, can cause hypopnea and apnea during sleep ${ }^{26}$.

Mixed sleep apnea (MSA) has features both of central and obstructive sleep apnea. During the same apneic period, the person tries to breathe by contracting abdominal/thoracic muscles (just like in OSA) in one part of the apneic period, while in the other part doesn't have muscle contractions (just like CSA). It is possible and not rare that patients experience episodes of central, obstructive and mixed apnea during the same night.

Common sleep apnea symptoms include snoring, breathing cessations, feeling of suffocatiing during the night, daytime tiredness, sleep during the day, reduced level of enthusiasm and concentration, morning headaches, dry mouth, etc. ${ }^{27}$. Snoring occurs due the relaxation of the uvula and soft palete which party block the airflow thus causing irregular flow of air and the unpleasant sound.

\section{DiAgnosis AND TREATMENT}

The gold standard for diagnosing sleep apnea in full-night polysomnography in a Center for Sleep Medicine under supervision of qualified personnel. Full-night polygraphy is also a valuable method, especially because the patients can sleep at home, but it doens not include the supervision of qualified personnel nor EEG which means

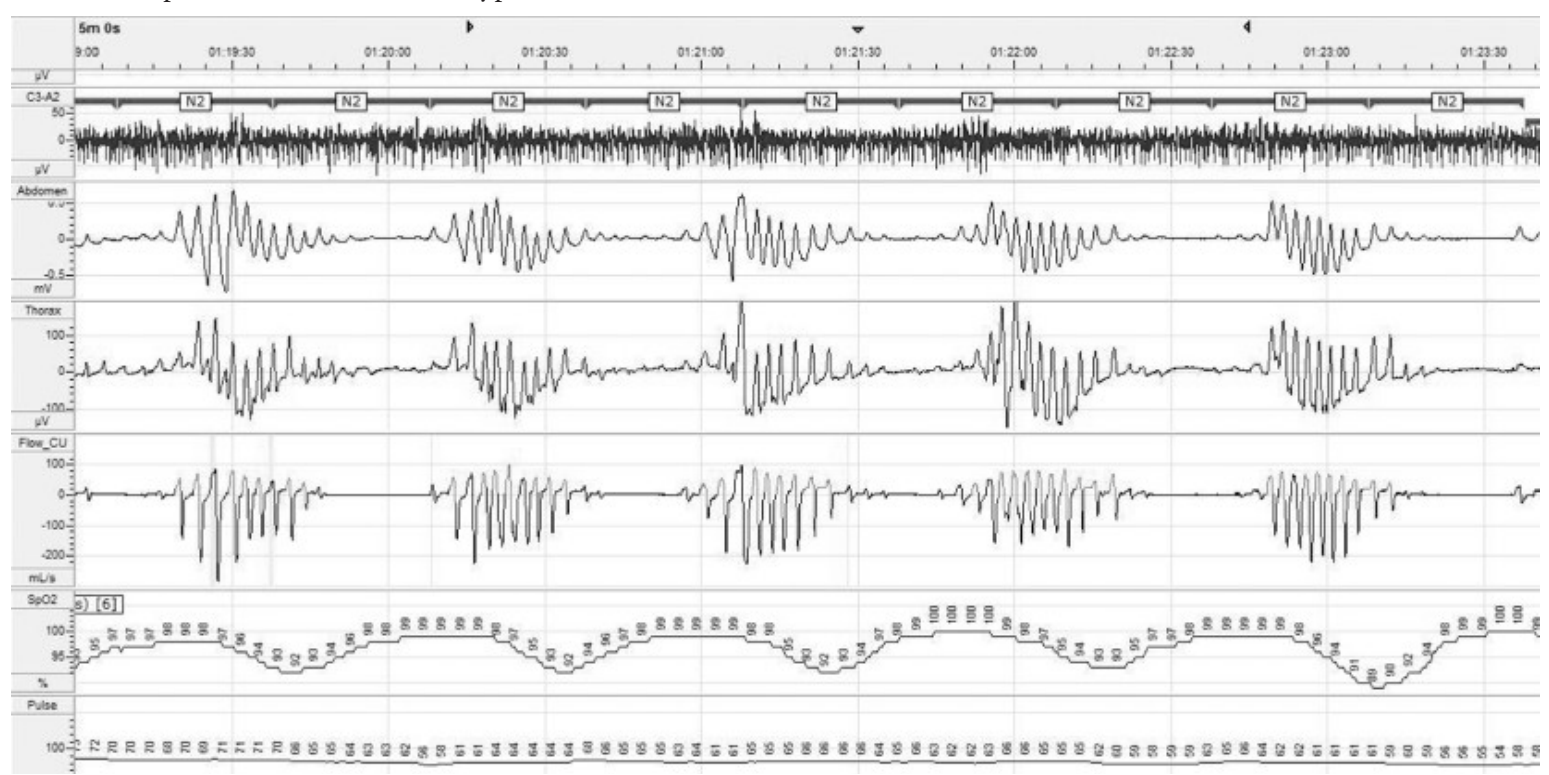

Figure 4. Central Sleep Apnea with Cheyne-Stokes Respiration Papern. Note the repetitive crescendoldecrescendo breathing papern (hypopnea-hyperpnea-hypopnea-apnea) during stage N2 non-REM sleep (circled). AOer each apnea there is a period of desaturation (SpO2 graph which is second to last on the picture). The rectangle represents the apnea, i.e. no breathing period. Note that only two out of five of Cheyne-Stokes breathing paperns are circled, one for the movement of abdominal muscles (upper row with circle) and the other for thoracic muscles (lower row with circle) ${ }^{21}$ 


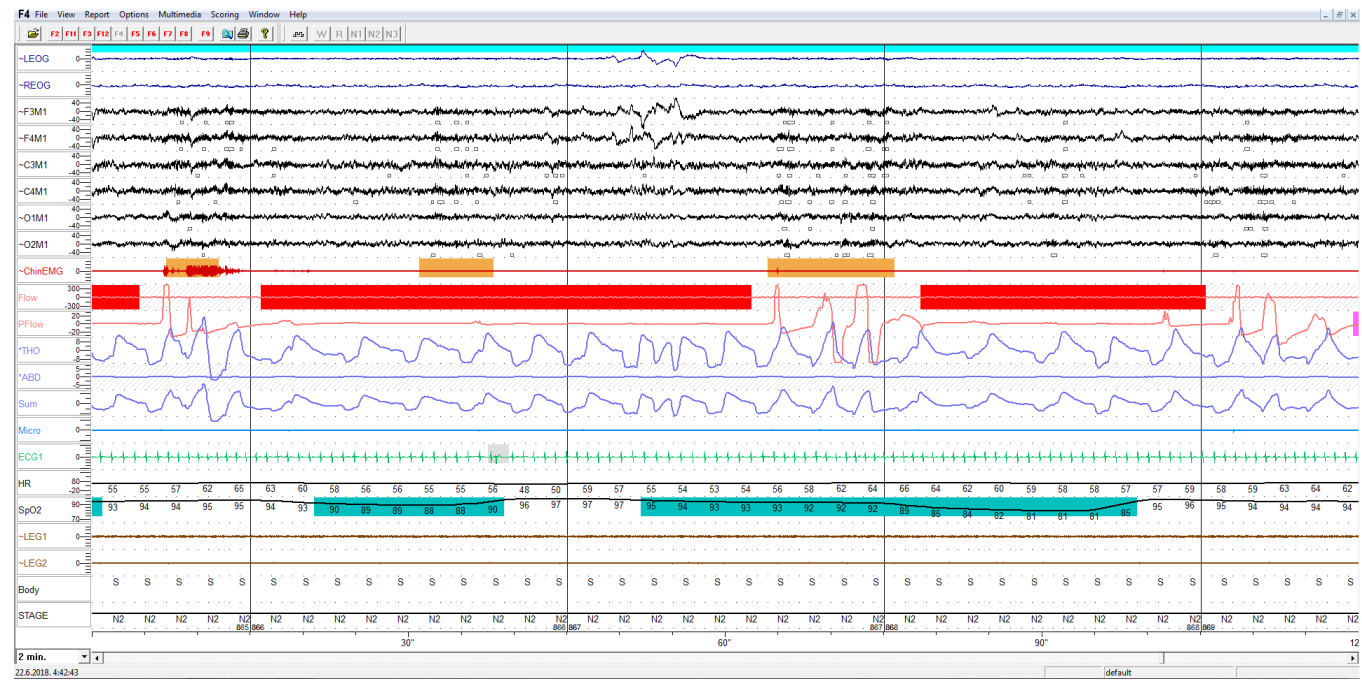

Figure 5. Polysomnographic Recording of Obstructive Sleep Apnea. Note the red rectangle in the "Flow" field and the flat line inside it indicating breathing cessation. "THO" and " $A B D$ " fields below it indicate that there is contraction of the thoracic and abdominal muscles (waves in the picture) because the person is trying to breathe but cannot due to the obstruction of the airflow (recording taken with permission from the Center for Sleep Medicine of the University of Split School of Medicine and University Hospital Split).

it cannot record sleep stages and sleep architecture disorders which can be of potentially great value. For the assesment of the risk of sleep apnea, patient fill out different questionnaires before potentially going to polysomnography/polygraphy recordings. Some examples of questionnaires are: Berlin Questionaire, STOP BANG, Pipsburgh Sleep Quality Index and others which are composed of questions regarding the symptoms of sleep apnea. STOP BANG is commonly used and is an abbreviation for: Snoring, Tiredness, Observed apnea, Pressure (arterial hypertension), BMI (risk for apnea above 35), Age (risk for apnea above 50), Neck (circumference above $40 \mathrm{~cm}$ at increased risk), Gender (male sex at more risk). Epworth Sleepiness Scale is an important scale which asseses the level of sleepiness while doing routine daily activities (watching TV, reading, etc.) because dytime tiredness is associated with sleep apnea ${ }^{28}$. For the assesment of risk of sleep apnea, the Mallampati score can also be used, althouth its primary purpose is the risk assesment of intubation in anesthesia. This simple test is performed in a way that the patient opens his/her mouth wide and the doctor asseses the visibility of the soft palete, tonsils, uvula and palatal arches. It has four categories, from category one (everything visable) to four (only hard palate visable). Higher Mallampati scores are associated with higher AHI (apnea-hypopnea index; the average number of apneas and/or hypopneas per hour of sleep) although some research questions the test's clinical value $e^{29,30}$. Sleep apnea can be diagnosed both with polygraphy and polysomnography. The main criteria for diagnosing sleep apnea is total breathing cessation of at least 10 seconds (oronasal airflow sensor) followed by desaturation of at least $3 \%$ (pulse oximeter). For distinguishing the types of apnea, the upper and lower belt are key. If at least one of the belts detects muscle contractions (movement of the thorax and/or abdomen) and there is no breathing for at least 10 seconds followed by desaturation of $3 \%$ or more, we conclude the existence of obstructive sleep apnea because the person is trying to breathe, but cannot due to a mechanical obstruction in the airway. If none of the belts detect any muscle contractions, along with more than 10 seconds of breathing cessation and desaturation of at least 3\%, we conclude that this is central sleep apnea.

Therefore, the key difference is that in obstructive apnea there are muscle contractions, whereas in central apnea there are not (Figure 5 and Figure 6). Furthermore, the severity of apnea is important to asses so we can treat it properly. The severity of apnea is indicated with the index called AHI (Apnea - Hypopnea Index). This index is calculated in a way that all apenas (all types) and hypopneas during sleep are added together and then divided with the number of hours spent sleeping. The end result (AHI) signifies the average number of apneas and/or hypopneas per hour of sleep. AHI below 5 is a state without sleep apnea. This means that the person that has less than 5 apneas and/or hypopneas per hour of sleep does not have a diagnosis of sleep apnea, but just sporadic episodes of apnea/hypopnea. AHI from 5 to 14.9 indicates mild sleep apnea, 15 to 29.9 moderate, while a result of more than 30 severe sleep apnea. In comparison, in children, AHI from 1 to 4.9 is classified as mild sleep apnea, 5 to 9.9 moderate and 10 and above severe ${ }^{31}$. There is another way of classifying sleep apnea and it is called RDI (Respiratory Disturbance Index). It is very similar to AHI, but apart from apneas and hypopneas, it also adds together phenomena called RERA (Respiratory Effort Related Arousal) and then divides all that with the number of hours of sleep. Values for diagnosis of mild, moderate and severe sleep apnea are the same as for AHI. RERA is a state which is characterized by obstruction (doesn't have to be complete) of the upper airways for at least 10 seconds and results in increased effort when trying to breathe but does not meet the criteria for apnea or hypopnea. The increased effort of breathing causes arousals and changes in EEG recordings to alpha waves. Therefore, that person goes to a state of relaxed wakefulness without being conscious of $\mathrm{it}^{32}$.

Apnea, in most cases, cannot be cured as such, but can be successfully treated and kept under control throughout life. Before the actual treatment, it is important to emphasize that a healthy and active lifestyle can greatly help decrease the risk for apnea and many other diseases. Sleeping with the upper body raised by $30 \%$, as well as sleeping on the side give more stability to the airway and significantly reduces the risk for sleep apnea ${ }^{33}$. The gold standard for treating any type of sleep apnea and drastically reducing the potential apnea complications is a device called CPAP (Continuous Positive Airway Pressure $)^{34}$. CPAP has a flexible tube and a mask on the end of it which is put on the nose and/or mouth depending on the model and is used only during sleep time (Figure 7). It blows air in the airway and lungs under positive pressure of $5-15 \mathrm{~cm}$ of water. During the whole period of sleep CPAP blows air in the upper airway under minimal and constant pressure after the pressure has been adjusted for each patient (process called titration). Therefore, from the evening when it is turned on, till the morning when it is turned off, CPAP constantly blows air under the same pressure into the airway, regardless if the person is exhaling or inhaling. Even after titration, some people find it difficult to exhale against the CPAP pressure and they are advised to try BiPAP (Bilevel Positive Airway Pressure). BiPAP is almost identical to CPAP but has two pressure levels, one when the patient is inhaling and one when exhaling (lower pressure) making it easier to breathe. APAP (Automatic Positive Airway Pressure) is similar to CPAP but instead of one or two levels of pressure, it automatically adjusts the pressure during the night to suit the patient. In summary, PAP (Positive Airway Pressure) devices blow air into the airway like an invert vacuum cleaner, thus keeping the airway opened and free of potential obstructions (tongue that falls back, hypotonia of soft palate and pharynx muscles) ${ }^{35}$. Also, when the patient is not breathing without any obstructions (central sleep apnea) they blow air inside the lungs eliminating apnea. PAP devices do not stop the hypotonia of the pharynx and soft palate muscles as such, but they do stop them from becoming an obstacle in the airway in case of 


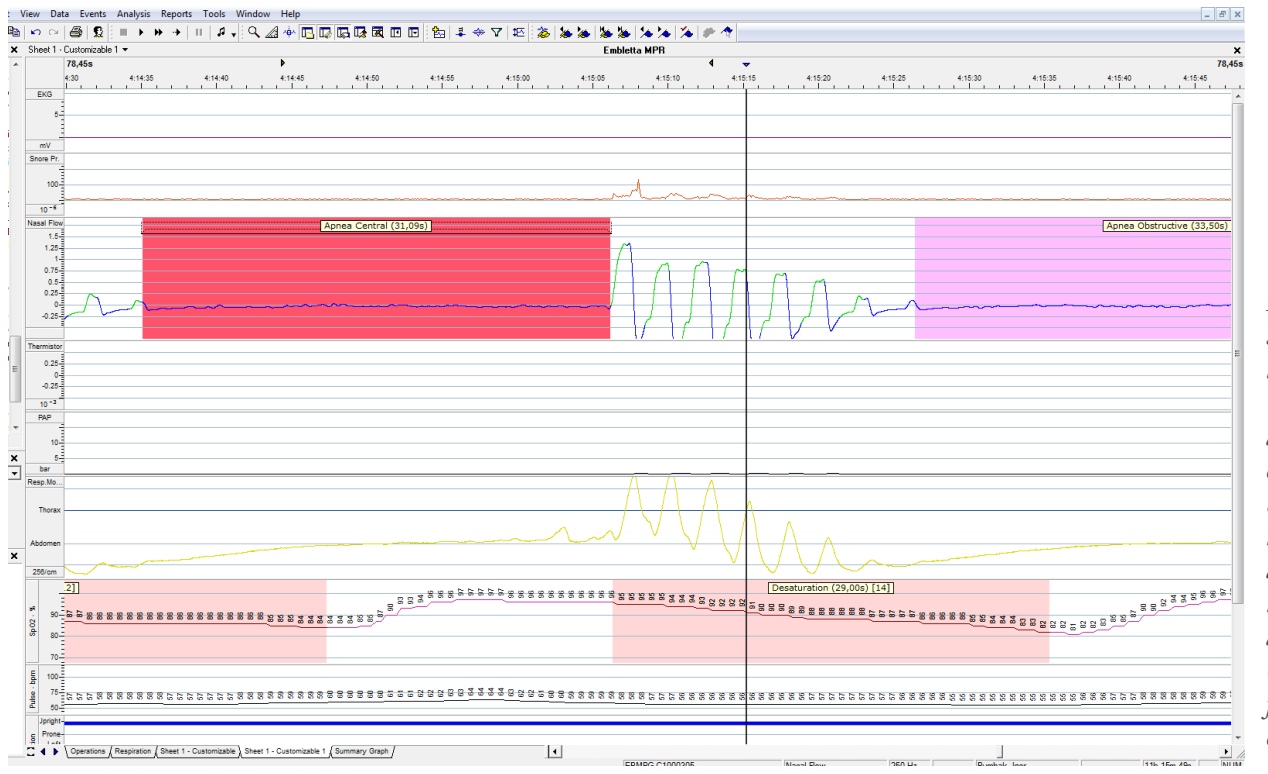

Figure 6. Polygraphic Recording With Central Sleep Apnea. Nothe the red rectange and the flat line inside it that represents breathing cessation. The field marked "Abdomen" below it shows an almost totally flat line indicating no contraction of abdominal muscles because the signal from the brain doesn't reach them. Desaturation occurs after the apneic period in the "SpO2" field marked by a falling line with desaturation values. Also note there are no $E E G$ resordings because this is not a polysomnographic, but polygraphic recording (recording taken with permission from the Center for Sleep Medicine of the University of Split School of Medicine and University Hospital Split).

their collapse. The successful use of CPAP together with an active and healthy lifestyle increases concentration and effectiveness, reduces daily tiredness, snoring, risk for diabetes and cardiovascular diseases and other complications of untreated apnea ${ }^{36-39}$. PAP devices are not an apnea cure because apnea quickly returns if the person stops using them. In Croatia, patients receive CPAP free of charge if their AHI is higher than 30 (severe apnea) or rarely in the event of moderate apnea if the patient fulfils at least three of the following additional criteria: obesity, daytime sleepiness, resistent arterial hypertension, unregulated diabetes and acute events like stroke or myocardial infarction. If none of the PAP devices are useful for the patient, ASV (Adaptive Servo-Ventilation) can be recommended. It looks similar to PAP devices, but it focuses more on the volume of air rather than pressure which is blown into the airway. This way, it broadens the airway and the patient can breathe.

Other methods for treating sleep apnea include: surgery, positional therapy and using the oral appliance (Figure 8). Surgical methods are useful in removing anatomical abnormalities in the upper airways. The most used method is uvulapalatopharyngoplasty (UPPP, UP3) where the adeonides and tonsils (lymphoid tissue) are removed, and the uvula, soft palate and the pharynx are corrected. It can usually help with snoring. Positional therapy is easier to execute. It consists of not sleeping on the back, but rather on the side due to the connection of sleeping on back with increased $\mathrm{AHI}^{40}$. There are many methods for avoiding sleeping on the back and one of the most innovative is stiching a tennis ball on the back side of the pajamas so every time the person turns on his/her back it will be uncomfortable and will immediately turn of to the side ${ }^{41}$. Sometimes the discomfort caused by the tennis ball wakes the patient up which reduces sleep quality.

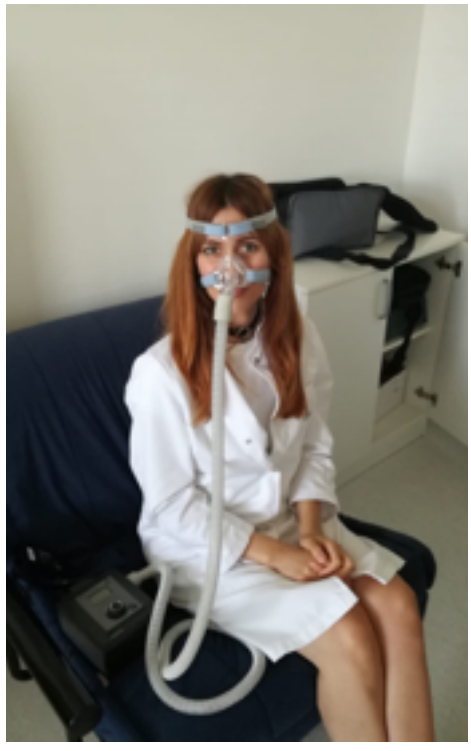

Figure 7. CPAP Device on a Model Patient. The device is used just during sleep. Usually there is a small water container in the device so air can be humidified before being blown in the airway. Otherwise, the unhumidified air can dry out the mouth and irritate the nasal mucosa. Patients need to get used to all PAP devices which may cause sneezing, dry mouth, irritation of nasal mucosa and other. A small number of patients cannot get used to PAP devices and they are advised to lose weight if obese, use oral appliances and surgery.
The oral appliance is put on the teeth only during sleep and protrudes the mandible forward, thus reducing the risk of the tongue falling backward. It also broadens the airway ${ }^{42}$. It is the treatment of choice for mild and moderate apneas when the patient cannot adapt to PAP devices. In Croatia, the patient has to pay for the appliance in full because it is not covered by health insurance ${ }^{43}$. An interesting treatment for moderate apnea is the use of the musical instrument didgeridoo. In this research, patients practiced playing the instrument six times a week and AHI, as well as daily tiredness reduced significantly. As the didgeridoo is a wind instrument, the underlying improvements are probably based on the strenghtening of oropharingeal muscles by blowing in the instrument and therefore reducing the risk of their collapse $e^{44}$. Another relatively new method of treating apnea is the stimulation of the $12^{\text {th }}$ cranial nerve (hypoglossal nerve) which innervates almost all tongue muscles (geniglossal, hypoglossal and other muscles). In a surgical method, a stimulator is implanted and connected to the nerve and by constant stimulation, it reduces the risk of airway collapse ${ }^{45}$. This method is still in its beginnings.

\section{Long-Term Complications of Untreated Sleep Apnea}

There are numerous complications that untreated sleep apnea can lead to. One of the dangerous ones is daytime fatigue and sleepiness, especially in professional drivers of buses, trucks and dangerous goods where it can increase the risk of having a road traffic accident by up to five times ${ }^{46}$. The conncection between obesity and the risk of sleep apnea has been evaluated many times in the past, but recent research shows that in the early age of adolescence neurocognitive problems can be a result of sleep apnea ${ }^{47,48}$. In older people who suffer from breathing related sleep disorders, the onset of mild cognitive impairment, which can lead to Alzheimer's disease, can be 10 to 11 years

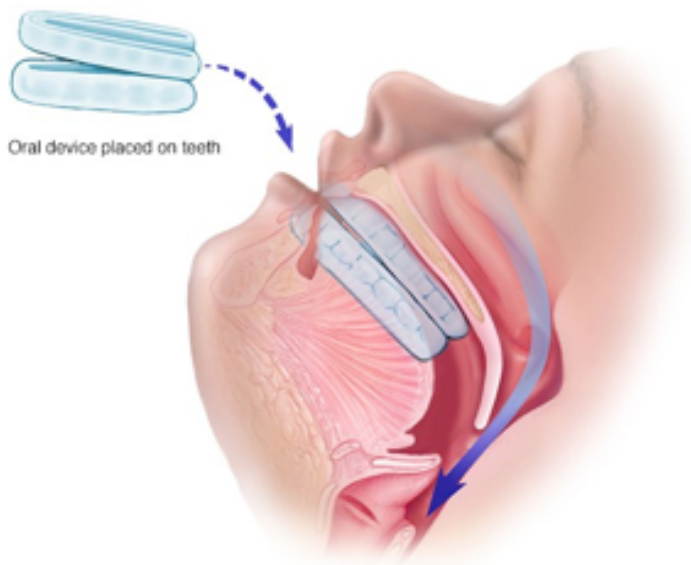

Figure 8. Oral Appliance - note that the use of the oral appliance prevents the tongue falling back and keeps the airway open. It is used in mild and moderate apneas (27). 


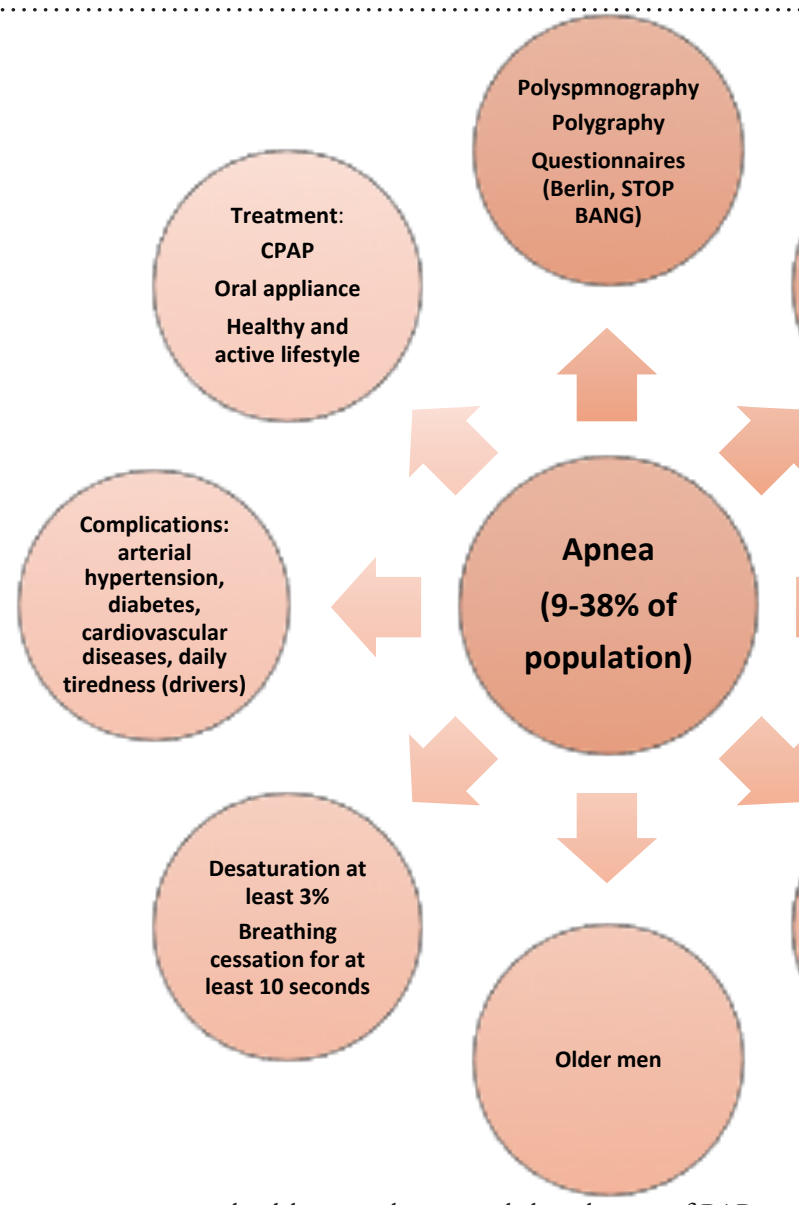

earlier in comparison to healthy population and that the use of PAP devices neutralizes that earlier onset ${ }^{49}$. An important complication of untreated apnea is the increased risk of cardiovascular diseases (myocardial infarction, atrial fibrillation, arterial hypertension), diabetes type 2, stroke, metabolic syndrome (obesity, elevated triglycerides, lipids, glucose and arterial pressure), liver disease (non-alcoholic fapy liver disease) and other ${ }^{50,51}$. One of the proposed connections between sleep apnea and cardiovascular disease is the occurrence of systemic inflammation and elevated inflammatory markers which decrease with apnea treatment. Furthermore, intermipent hypoxia, i.e. the exchange of normoxia (when there is no apnea) and hypoxia (apneic event), can induce an inflammatory reaction which can negatively impact the cardiovascular system ${ }^{52}$. Because of oxygen reduction, and $\mathrm{CO} 2$ increase during and following the apneic event, the sympathetic nervous system is activated. Peripheral chemoreceptors in the carotid and aortal body activate it primarily because of hypoxia (but because of hypercapnia as well). The result is vasoconstriction which increases arterial pressure and the load on the heart until the levels of $\mathrm{O}_{2}$ and $\mathrm{CO}_{2}$ in the blood normalize. The normalization usually comes aOer the apneic event. The next apnea causes the same sympathetic activation again and the repetition of the described papern. This is repeated tens of hundreds of times during just one night, let alone for weeks, months, years and decades if apnea is leO untreated. This causes severe changes in the organism in the form of arterial hypertension, cardiovascular diseases and sympathetic dysfunction. If the person had been diagnosed with arterial hypertension prior to apnea, it can worsen $^{53}$. Elevated sympathetic activity leads to significantly increased peripheral insulin resistance, which together with repetitive periods of hypoxia during apnea and the shortened sleep time, increase the risk of diabetes type $2^{54}$. Daily tiredness and lowered concentration levels in drivers reduce the likelihood of appropriate driving manners and increase the risk of road traffic accidents which can have fatal consequences. The underlying cause of daily tiredness are so called micro-awakenings which occur frequently after the apneic events. While the patient is going through an apneic episode, the body fights to breathe and the muscles contract in OSA. The resulting hypoxia and hypercapnia right after the apnea cause a series of very deep and powerful breaths to normalize the concentration of blood gases which
Figure 9. Fundamentals of Sleep Apned

"wake up" the patient (EEG alpha waves) without him/her ever being conscious of it. If the patient exhibits numerous micro-awakening during the night, sleep architecture and quality will become disrupted because constant transition to alpha waves (constant apneas and micro-awakenings) from whichever sleep stage prevents patients from spending sufficient time in deep sleep stages which are extremely important for rest. If this is the case, the patient will feel tired, lacklustre and with poor energy and concentration during the day.

\section{Aim AND HyPOTHESIS}

The aim of this research is to find a connection between body position during sleep and severity of obstructive sleep apnea (OSA) in patients with newly diagnosed OSA after full-night polysomnography. Regarding on written, the hypothesis reads: „The severity of OSA will be significantly higher while sleeping on the back in comparison to sleeping on the left or right side."

\section{Subjects And Merhods}

This research is a cross-sectional and clinical research. 414 patients (281 male and 133 female) who came in 2017 for diagnostic purposes to the School of Medicine and University Hospital Split Center for Sleep Medicine were included in the research. Demographic data of the patients was taked from the archive of the Center for Sleep Medicine. All patients underwent full-night polysomnography with the device Alice 5LE, Philips Respironics, Eindhoven, The Netherlands. The diagnosis, as well as the severity of the sleep disorder, was evaluated with AHI after the full-night polysomnography, all in accordance with the American Academy of Sleep Medicine (AASM) and European Sleep Research Society (ESRS) guidelines for OSA diagnosis. Patients under 18 years of age and patients who underwent full-night polygraphy were not included in the study.

\section{Questionnaires}

All patients who undergo full-night polysomnography in the Center for Sleep Medicine in Split, Croatia fill out a few questionnaires which are frequently used to asses risk for OSA, as well as daytime sleepiness. Epworth Sleepiness Scale

Epworth Sleepiness Scale which is validated in Croatian was used to 
Original Article

Table 2. Sleep architecture in relation to full-night polysomnography findings and patient's sex

\begin{tabular}{|ll|l|l|l|}
\hline \multicolumn{1}{r}{ Variables } & \multicolumn{1}{c}{ Total } & \multicolumn{1}{c|}{ W } \\
\hline Sex (N) & 414 & 281 & 133 & \\
N1 (min, \%) & $19.7 \pm 31.1(5.2)$ & $21.6 \pm 31.8(5.6)$ & $12.6 \pm 18.6(3.2)$ & $<0.001$ \\
N2 (min, \%) & $267.8 \pm 75.9(70.1)$ & $264.8 \pm 79.0(69.6)$ & $258.4 \pm 65.3(68.1)$ & 0.014 \\
N3 (min, \%) & $35.5 \pm 30.3(9.3)$ & $34.2 \pm 28.9(8.9)$ & $47.2 \pm 32.8(12.5)$ & 0.091 \\
REM (min, \%) & $59.6 \pm 34.4(15.5)$ & $59.8 \pm 33.6(15.9)$ & $61.6 \pm 33.9(16.2)$ & 0.865 \\
Sleep time (min) & $382.1 \pm 77.8$ & $379.7 \pm 82.2$ & $378.5 \pm 72.3$ & 0.095 \\
Sleep efficacy (\%) & $77.8 \pm 15.3$ & $77.4 \pm 16.4$ & $77.1 \pm 13.0$ & 0.003 \\
\hline
\end{tabular}

$M-$ men, $W$ - women, N1 - stage 1 sleep, N2 - stage 2 sleep, N3 - stage 3 sleep, REM - Rapid Eye Movement

asses sleepiness during routine daily activities ${ }^{55}$. The questionnaire is formed out of 8 statements which describe everyday activities (sitting and reading, watching TV, sitting at a meeting while not actively participating in it, being in a car for more than an hour as a passenger, sitting after a meal whitout alcoholic beverage, sitting and talking to someone, sitting in the car in a traffic jam for a few minutes, lying and relaxing in the living room). The patient has to answer every statement with on of the following answers which are scored on a Likert scale in following way:

$$
\begin{aligned}
& 0 \text { - no need for sleep } \\
& 1 \text { - mild need for sleep } \\
& 2 \text { - moderate need for sleep } \\
& 3 \text { - irresistible need for sleep }
\end{aligned}
$$

The total number of points ranges from 0 to 24 . Normal values are between 0 and 6, 7 and 8 indicate moderate level of daytime sleepiness, while 9 to 24 high level of daytime sleepiness. Patients with high level of daytime sleepiness should undergo further evaluations ${ }^{55}$.

\section{Statistical procedures}

The statistical program Statistica v 8.0 (StatSoft, Inc., Tulsa, OK, USA) was used for statistical analysis. Quantitative variables are represented as mean values and standard deviations, while categorical variables as whole numbers and percentage. Student's t-test for independent samples and Chi-squared test were used for the analysis of demographic properties of patients in relationto OSA diagnosis, full-night polysomnography findings in relation to body position during sleep, as well as for the distribution of apneas and hypopneas in patients with diagnosed OSA. Furthermore, Pearson correlation coefficient was used to evaluate the connection between $\mathrm{AHI}$ and body position during sleep. The level of statistical significance was set at $\mathrm{P}<0.05$.

\section{RESULTS}

The research included 414 patients ( 281 male and 133 female). Their demographic characteristics are shown in Table 1. Median age for male patients is 54 years and for female 56. Men had greater neck circumference, higher body mass and bigger body mass index in comparison to women (Table 1). Furthermore, average AHI was larger in men than in women $(29.8 \pm 25.0$ vs. $12.4 \pm 12.6, \mathrm{P}<0.001$, Table 1$)$ and men were significantly more sleepy in comparison to women according to the results from the Epworth Sleepiness Scale (Table 1). All patients underwent full-night polysomnography in the Center for Sleep Medicine in Split, Croatia. The polysomnography results indicate that patients spend the least ammount of time in sleep stage 1 , and the most in sleep stage $2(5.2 \%$ in comparison to $70.1 \%$ of total sleep time, Table 1, Figure 10). Men spend more time in stage 1 (21.6 $\pm 31.8 \mathrm{~min}$ vs. $12.6 \pm 18.6 \mathrm{~min}, \mathrm{P}<0.001$, Table 2$)$ and stage 2 (264.8 \pm 79.0 min vs. $258.4 \pm 65.3 \mathrm{~min}, \mathrm{P}=0.014$, Table 2 ) in compari-

Table 1. Demographic characteristics of patients

\begin{tabular}{ll|lll|}
\hline Variables & Total & Men & Women & $\mathrm{P}$ \\
\hline Age (years) & $55(18-82)$ & $54(18-80)$ & $56(20-82)$ & 0.319 \\
Height $(\mathrm{cm})$ & $175.9 \pm 10.0$ & $180.8 \pm 7.4$ & $165.9 \pm 6.7$ & $<0.001$ \\
Weight $(\mathrm{kg})$ & $88.9 \pm 18.7$ & $96.0 \pm 16.3$ & $74.1 \pm 14.1$ & $<0.001$ \\
BMI $\left(\mathrm{kg} / \mathrm{m}^{2}\right)$ & $28.5 \pm 4.8$ & $29.4 \pm 4.5$ & $26.8 \pm 4.9$ & $<0.001$ \\
Neck circumference $(\mathrm{cm})$ & $40.9 \pm 4.7$ & $43.2 \pm 3.5$ & $36.2 \pm 3.4$ & 0.002 \\
ESS result & $7.3 \pm 4.8$ & $7.6 \pm 4.7$ & $6.3 \pm 4.8$ & 0.021 \\
AHI & $24.2 \pm 23.2$ & $29.8 \pm 25.0$ & $12.4 \pm 12.6$ & $<0.001$ \\
\hline
\end{tabular}

BMI - body mass index, ESS - Epworth Sleepiness Scale, AHI - apnea-hypopnea index son to women which is statistically significant.

In accordance to AHI value, the patients were diagnosed with OSA. If value of $A H I \geq 5$, patients were diagnosed with OSA while patients with $\mathrm{AHI}<5$ are considered helathy. The total number of paitents with $\mathrm{AHI} \geq 5$ was $317(78 \%)$, while $92(22 \%)$ had $\mathrm{AHI}<5$. Out of the total number of patients with diagnosed OSA $74 \%$ were men and $26 \%$ women (Table 3). A difference in age, BMI and neck circumference was found betweent the two groups where OSA patients (AHI $\geq 5$ ) were older, had larger neck circumference and BMI in comparison to patients who weren't diagnosed with OSA (Table 3). The level of daytime sleepiness was not statistically different in patients with and withous diagnosed OSA ( $7.5 \pm 4.8$ vs $6.5 \pm 4.5, \mathrm{P}=0.071$, Table 3$)$. Furthermore, the connection of AHI value with body position during sleep was researched in the whole sample of 414 patients. On average, patients slept the most time on their back, and the least on the right side $(189.9 \pm 118.4 \mathrm{~min}$ vs. $80.6 \pm 90.6 \mathrm{~min}$, Table 4$)$. Also, AHI was found to be the largest when patients slept on their back (31.1 \pm 31.9 , Table 4). Using Student's t-test for independent samples, AHI value was found to be statistically significantly higher when patients slept on their back $(\mathrm{AHI}=31.1 \pm 31.9)$ rather than the left $(\mathrm{AHI}=18.9 \pm 24.1)$ or right side $(14.7 \pm 24.1)$. Detailed description of these results can be found in Table 4. Patients with OSA also had statistically significantly higher AHI value while sleeping on the back $(\mathrm{AHI}=39.1 \pm 31.9)$ in comparison to the left $(\mathrm{AHI}=23.8 \pm 25.2)$ or right side $(\mathrm{AHI}=18.5 \pm 25.6)$.

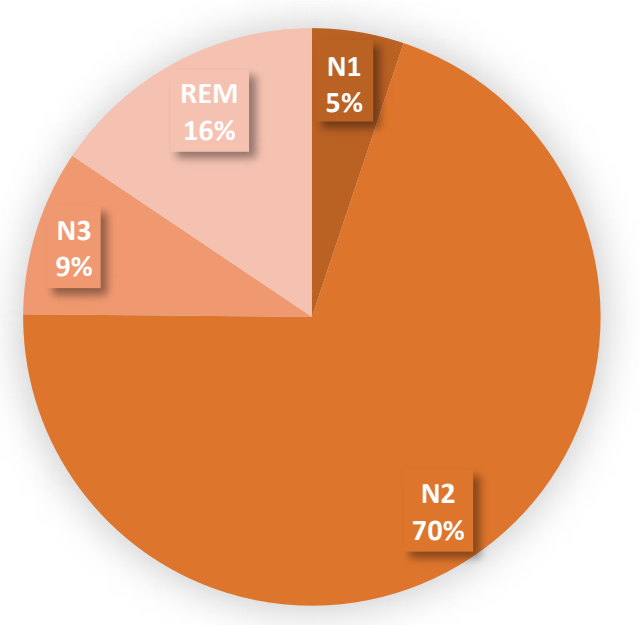

Figure 10. Figure 10. Representation of sleep stages in sleep architecture according to full-night polysomnography results. (N1 - stage 1 sleep, N2 - stage 2 sleep, N3-stage 3 sleep, REM - Rapid Eye Movement)

Furthermore, in patients with diagnosed sleep apnea (AHI $\geq 5)$, the most common type is obastructive apnea, and the least common central apnea ( $72.6 \%$ vs. $9.7 \%$, Table 5). Also, men had significantly more obstructive, central and mixed apneas, as well as total number of apneas and hypopneas in comparison to women $(\mathrm{P}<0.001$, Table 5$)$. Using Pearson Correlation Coefficient, we examinde the connection between $\mathrm{AHI}$ and time spent in a specific body position during sleep. There is a negative correlation between AHI and sleep time on the right side in patients with OSA $(\mathrm{r}=-0.178, \mathrm{P}=0.005$, Figure $11-\mathrm{B})$. In OSA patients there is a positive correlation between AHI and sleep time on the left side $(r=0.003, P=0.959$, Figure $11-\mathrm{A})$, as well as on 
Table 3. Demographic characteristics of patients in relation to OSA. AHI $<5$ doesn't have OSA, AHI $\geq 5$ has OSA.

\begin{tabular}{|c|c|c|c|c|}
\hline \multirow{2}{*}{\multicolumn{2}{|c|}{ Variables* }} & $\mathrm{AHI}<5$ & $\mathrm{AHI} \geq 5$ & \multirow{2}{*}{$\mathrm{P}$} \\
\hline & & $\mathrm{N}=92$ & $\mathrm{~N}=317$ & \\
\hline \multirow[t]{2}{*}{$\operatorname{Sex}(N, \%)$} & M & 43 (15.5) & $234(84.5)$ & \multirow{2}{*}{$<0.001 *$} \\
\hline & W & 49 (37.1) & $83(62.9)$ & \\
\hline \multicolumn{2}{|c|}{ Age (godine) } & $45(18-72)$ & $56(20-82)$ & $<0.001^{* *}$ \\
\hline \multicolumn{2}{|c|}{ BMW $\left(\mathrm{kg} / \mathrm{m}^{2}\right)$} & $25.3 \pm 4.1$ & $29.5 \pm 4.6$ & $<0.001 * *$ \\
\hline \multicolumn{2}{|c|}{$\begin{array}{l}\text { Neck circumference } \\
(\mathrm{cm})\end{array}$} & $37.4 \pm 3.9$ & $42.0 \pm 4.4$ & $<0.001^{* *}$ \\
\hline \multicolumn{2}{|l|}{ ESS result } & $6.5 \pm 4.5$ & $7.5 \pm 4.8$ & $0.071^{* *}$ \\
\hline
\end{tabular}

Table 4. Full-night polysomnography findings in regard to body position during sleep

\begin{tabular}{|c|c|c|c|c|}
\hline Variables & $\begin{array}{l}\text { Total - all body } \\
\text { positions }\end{array}$ & Left side & Back & Right side \\
\hline 1. Sleep time (min) & 1. $379.8 \pm 78.6$ & $\begin{array}{ll}\text { 1. } & 113.3 \pm 9 \\
0.9\end{array}$ & $\begin{array}{ll}\text { 1. } & 189.9 \pm 11 \\
8.4\end{array}$ & 1. $80.6 \pm 90.6$ \\
\hline 1. $\mathrm{AHI}$ & 1. $24.2 \pm 23.2$ & $\begin{array}{ll}\text { 1. } & 18.9 \pm 24 \text {. } \\
1\end{array}$ & 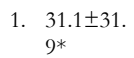 & 1. $14.7 \pm 24.1$ \\
\hline 1. $\mathrm{AHI} \geq 5$ & 1. $30.8 \pm 22.4$ & $\begin{array}{l}\text { 1. } 23.8 \pm 25 \text {. } \\
2\end{array}$ & $\begin{array}{l}\text { 1. } 39.1 \pm 31 \text {. } \\
9\end{array}$ & 1. $18.5 \pm 25.6$ \\
\hline
\end{tabular}

Table 5. Representation of apneas and hypopneas in patients with diagnosed sleep apnea (AHI $\geq 5)$ according to full-night polysomnpgraphy.

\begin{tabular}{|c|c|c|c|c|}
\hline Variables* & Total & M & W & $\mathrm{P}$ \\
\hline $\begin{array}{l}\text { Obstructive apnea }(\mathrm{N}, \\
\%)\end{array}$ & $\begin{array}{l}74.2 \pm 93.1 \\
(72.6)\end{array}$ & $\begin{array}{l}73.9 \pm 98.2 \\
(71.9)\end{array}$ & $\begin{array}{l}20.9 \pm 34.8 \\
(76.0)\end{array}$ & $<0.001$ \\
\hline Central apnea $(\mathrm{N}, \%)$ & $9.9 \pm 17.6(9.7)$ & $9.8 \pm 17.8(9.6)$ & $3.7 \pm 9.3(13.5)$ & $<0.001$ \\
\hline Mixed apneja (N, \%) & $\begin{array}{l}18.3 \pm 38.8 \\
(17.9)\end{array}$ & $\begin{array}{l}19.4 \pm 40.8 \\
(18.9)\end{array}$ & $2.9 \pm 5.6(10.6)$ & $<0.001$ \\
\hline Total apneas (N) & $102.2 \pm 122.9$ & $102.8 \pm 130.2$ & $27.5 \pm 41.0$ & $<0.001$ \\
\hline Hypopnea (N) & $97.2 \pm 66.3$ & $89.6 \pm 71.7$ & $50.8 \pm 53.5$ & $<0.001$ \\
\hline
\end{tabular}

the back $(r=0.183, P=0.002$, Figure 11-C).

\section{Discussion}

The results of the research show that patients who underwent fullnight polysomnography in the Center for Sleep Medicine in Split, Croatia spend the most time on their back during sleep. In this position, they have significantly higher AHI value in comparison to sleeping on left or right side. At the same time, AHI positively correlates with the time spent sleeping on the back and left side, while negatively with sleeping on the right side.

Previous research show that sleeping on the back increases the risk of upper airway collapse ${ }^{56}$. Also, avoiding sleeping on the back contributes to reduction of the number and duration of repeated episodes of upper airway obstruction, especially in patients with mild and moderate apneas ${ }^{57,58}$. According to some research, it is estimated that almost $60 \%$ of OSA patients, that diagnosis has to do with sleeping on the back ${ }^{59}$. Furthermore, in an article by Menon and Kumar about the influence of body position during sleep on OSA, patients with diagnosed OSA can be classified in two groups: positional and nonpositional OSA ${ }^{60}$. Positional OSA group is the one in which the RDI (Respiratory Disturbance Index) value is more than twice as large on the
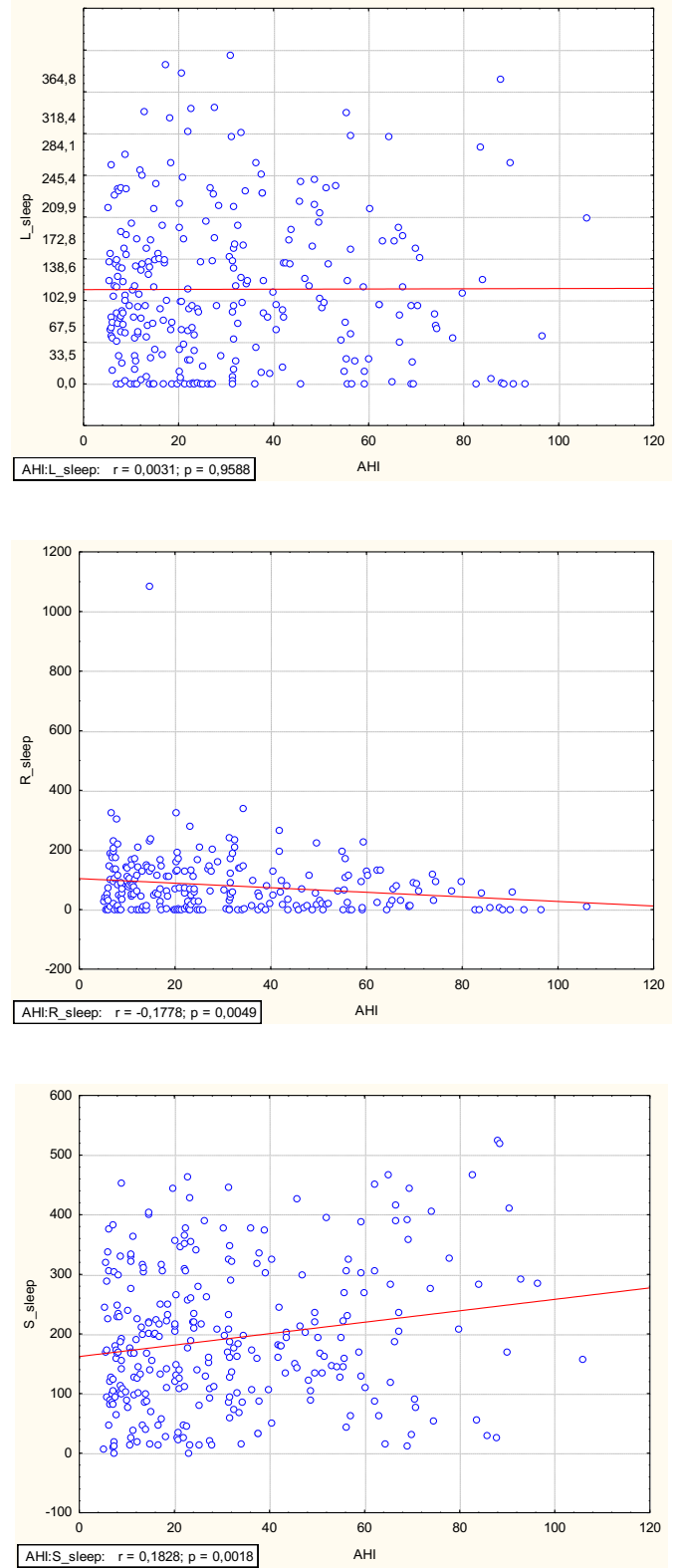

Figure 11. Correlation (Pearson Correlation Coefficient) between Apnea-Hypopnea Indeks (AHI) and time spent in specific body position during sleep; position on left side (L_sleep, $A)$, right side (R_sleep, $B)$ and back (S_sleep, $C)$ during sleep in patients who are diagnosed with obstructive sleep apnea (AHI $\geq 5)$.

back position in comparison to the left and right side. Nonpositional OSA group is defined as the group where OSA patients have the RDI value less than twice as large on the back in comparison to the right or left side. Frank et al. define positional OSA with the AHI or ODI (oxygen desaturation index) ratio in the back position in comparison to other body positions while speeping in the ratio $\geq 2$ ili $>2(61,62)$. A very important variable which is being discussed in literature is the effect of the diagnostic procedure on the level of OSA considering that more than $50 \%$ of time during full-night polysomnography patients spend sleeping on their back because of the equipment and electrodes to which they are connected which is not the case when 
sleeping at home in a natural environment ${ }^{63,64}$. Therefore, there is a possibility of overestimating the level of OSA in diagnostic procedures because of more time spent on the back position which can also be a limiting factor to our study too. Furthermore the influence of body position on OSA severity is being discussed in terms of treatment options. Research show indicate posture-control devices as a method of treating OSA as they are significantly more sophisticated than their usual therapeutic approach such as sewing a tennis ball to the back of the pajamas or applying various improvised equipment to avoid sleep on the back position ${ }^{65}$. Previous research show that positional therapy is useful in treating patients with mild moderately severe OSA ${ }^{58,59,65}$. Results from our research show that patients spend significantly more time during sleep on their back in comparison to side positions which is in accordance to the published research about full-night polysomnography in Center for Sleep Medicine conditions. Also, AHI value is larger when sleeping on the back in comparison to side positions up in patients with diagnosed OSA (AHI $\geq 5)$.

The effects of body position on certain sleep stages show that body position differently affects REM and non-REM sleep in a way that the increase in $\mathrm{AHI}$ while sleeping on the back is more emphasized during non-REM sleep stage ${ }^{66}$. According to our research, non-REM sleep stages take up around 84\% and REM stage 16\% of total sleep time. Stage 2 non-REM sleep is the longest (70\%) and stage 1 the shortest $(5 \%)$ in total sleep time.

It is a well known fact that BMI and older age affect time being spent on sleeping on the back $^{64}$. Our research show that our patients are middle to older aged (age median is 55 years) who have higher BMI $(28.5 \pm 4.8 \mathrm{~kg} / \mathrm{m} 2)$ with the average AHI of $24.2 \pm 23.2$. When sex is taken into account, men were significantly taller, had higher BMI and neck circumference in comparison to women. Similar results were found in studies from Huand et al. in regard to BMI and Dancey et al. in regard to neck circumference ${ }^{67,68}$. Furthermore, Epworth Sleepiness Scale score was significantly higher in men in comparison to women which suggests higher daytime sleepiness. Daytime sleepiness is also negatively affected by the significantly higher AHI value in men which is expected if we take into consideration the well known fact that the higher level of OSA negatively affect sleep quality, impairs sleep integrity and architecture, and causes frequent microarousals and awakenings.

Our research shows that the male sex is a significant risk factor for OSA. This result was confirmed by the research done by Senaratna et al. where they concluded that the prevalence of OSA among people older that 18 is between $9 \%$ and $38 \%$. In men, the prevalence was between $13 \%$ and $33 \%$, while in women $6 \%$ to $19 \%{ }^{12,69}$. According to Cairns et al., the middle age is a good predictor for OSA, especially in women ${ }^{70}$. Heizner et al. show that the prevalence of sleep apnea in men aged between 40 and 60 is significantly higher than in women
$(79.6 \% \text { in comparison to } 46.7 \%)^{71}$. Namely, OSA is associated with a whole series of cardiometabolic disorders and the increase in total morbidity and mortality in the population ${ }^{72}$. Timely intervention and treatment of OSA can not only improve quality of life, but also many hemodynamic and metabolic parameters which can in the end lead to reduced risk for various diseases.

This research has its limitations in the sense that it included only patients who underwent full-night polysomnography so the results cannot be applicable to the whole OSA population because a certain number od patients undergo full-night polygraphy in the patient's home. Also, it is shown in literature that the accuracy of determining body position during sleep with specific sensors is a variable worth thinkong about. Namely, watching the patient's body position with a camera in the room which is done by qualified presonnel gives more realistic data about body position ${ }^{73}$. Our research relied on sensors which can be a limiting factor. Results of our research confirmed the hypothesis that the level of severity of OSA will be significantly higher when sleeping on the back position in comparison to the left or right side. What is left to research is the effect of positional therapy and/or reduction of weight on the severity of OSA in our patient population. Finally, further research is needed to more precisely determine the mechanisms undelying positional and nonpositional OSA and to create algorithms which would clearly define the course of action to determine diagnosis and choose the method of treatment for OSA patients associated with body position during sleep.

\section{Conclusion}

Men with diagnosed OSA have larger neck cirmumference, weight and body mass indeks in comparison to women. Furthermore, men with diagnosed OSA have higher AHI value, as well as Epworth Sleepiness Scale score in comparison to women. Regarding sleep architecture, stage 1 and stage 2 non-REM sleep was longer in men than in women with OSA. OSA patients spent the most time sleeping on their back and AHI value was statistically higher (39.1 \pm 31.9$)$ in that position than on the left $(23.8 \pm 25.2)$ or right $(18.5 \pm 25.6)$ side. The total number of obstructive, mixed and central apneas, as well as hypopneas was higher in men that in women with OSA which is statistically significant. A positive correlation was found between AHI value and sleeping on the left side and back, while a negative one between $\mathrm{AHI}$ value and sleeping on the right side.

\section{AUTHOR CONTRIBUTIONS:}

All authors listed have made a substantial, direct and intellectual contribution to the work, and approved it for publication.

\section{LITERATURE:}

1. Zee PC, Attarian H, Videnovic A. Circadian rhythm abnormalities. Continuum (Minneap Minn). 2013;19(1 Sleep Disorders):132-47.

doi: $10.1212 / 01$.

2. Bassetti CL, Dogas Z, Peigneux P. Sleep Medicine Textbook. Singapore: Wiley; 2014.

3. Hirshkowitz M, Whiton K, Albert SM, Alessi C, Bruni O,

DonCarlos L, et al. National Sleep Foundation's sleep time duration recommendations: methodology and results summary. Sleep Health.
2015;1(1):40-3. doi: 10.1016/j.sleh.2014.12.010.

4. Ohayon MM, Carskadon MA, Guilleminault C, Vitiello MV. Meta-analysis of quantitative sleep parameters from childhood to old age in healthy individuals: developing normative sleep values across the human lifespan. Sleep. 2004;27(7):1255-73. doi: 10.1093/ sleep/27.7.1255.

5. Foundation NS: Animals' Sleep: Is There a Human Connection? [Internet]. Available from: https://www.sleepfoundation.org/sleep- 
news/animals-sleep-there-human-connection [cited 2019 Jul 27]. 6. Sehgal A. Physiology Flies with Time. Cell. 2017;171(6):1232-5. doi: 10.1016/j.cell.2017.11.028.

7. Sehgal A, Mignot E. Genetics of sleep and sleep disorders. Cell. 2011;146(2):194-207. doi: 10.1016/j.cell.2011.07.004.

8. JJO dM. Observation botanique. Histoire de l'Academie Royale des Sciences. 1729:35-6.

9. Pickard GE, Sollars PJ. Intrinsically photosensitive retinal ganglion cells. Rev Physiol Biochem Pharmacol. 2012;162:59-90. doi: 10.1007/112_2011_4.

10. Graham DM, Wong KY, Shapiro P, Frederick C, Pattabiraman K, Berson DM. Melanopsin ganglion cells use a membrane-associated rhabdomeric phototransduction cascade. J Neurophysiol. 2008;99(5):2522-32. doi: 10.1152/jn.01066.2007.

11. Kofuji P, Mure LS, Massman LJ, Purrier N, Panda S, Engeland WC. Intrinsically Photosensitive Retinal Ganglion Cells (ipRGCs) Are Necessary for Light Entrainment of Peripheral Clocks. PLoS One. 2016;11(12):e0168651. doi: 10.1371/journal.pone.0168651. 12. Senaratna CV, Perret JL, Lodge CJ, Lowe AJ, Campbell BE, Matheson MC, et al. Prevalence of obstructive sleep apnea in the general population: A systematic review. Sleep Med Rev. 2017;34:70-81. doi: 10.1016/j.smrv.2016.07.002.

13. Association AS: Sleep and Sleep Disorder Statistics [Internet]. Available from: https://www.sleepassociation.org/sleep/sleep-statistics/ [cited 2019 Jul 27].

14. Health NIo: Sleep Apnea [Internet]. Available from: http://www. nhlbi.nih.gov/health/health-topics/topics/sleepapnea/ [cited 2019 Jul 27].

15. Patil SP, Schneider H, Schwartz AR, Smith PL. Adult obstructive sleep apnea: pathophysiology and diagnosis. Chest. 2007;132(1):32537. doi: 10.1378/chest.07-0040

16. Schwab RJ, Gupta KB, Geser WB, Metzger LJ, Hoffman EA, Pack AI. Upper airway and sos tissue anatomy in normal subjects and patients with sleep-disordered breathing. Significance of the lateral pharyngeal walls. Am J Respir Crit Care Med. 1995;152(5 Pt 1):1673-89. doi:10.1164/ajrccm.152.5.7582313

17. Davies RJ, Stradling JR. The relationship between neck circumference, radiographic pharyngeal anatomy, and the obstructive sleep apnoea syndrome. Eur Respir J. 1990;3(5):509- 14.

18. Sateia JM. International Classification of Sleep Disorders-Third Edition. Chest. 2014;146(5):1387-1394. doi: 10.1378/chest.14-0970. 19. Clinic M: Obstructive sleep apnea 2018 [Internet]. Available from: http://www.mayoclinic.org/diseases-conditions/obstructive-sleep-apnea/home/ovc-20205684 [cited 2019 Jul 27].

20. Eckert DJ, Jordan AS, Merchia P, Malhotra A. Central sleep apnea: Pathophysiology and treatment. Chest. 2007;131(2):595-607. doi: $10.1378 /$ chest.06.2287.

21. Pedrosa RP, Drager LF, Antunes MO, Arteaga E, Lorenzi-Filho G. Cheyne-stokes respiration associated with hypertrophic cardiomyopathy and normal les ventricular ejection fraction. Clinics (Sao Paulo). 2010;65(9):927-9. doi: 0.1590/S1807-59322010000900017.

22. Muza RT. Central sleep apnoea-a clinical review. J Thorac Dis. 2015;7(5):930-7. doi: 10.3978/j.issn.2072-1439.2015.04.45.

23. Advisor C: Central Sleep Apnea Syndrome [Internet]. Available from: https://www.clinicaladvisor.com/pulmonary-medicine/central-sleep-apnea-syndrome- idiopathic-csa-cheyne-stokes-respirationcsa-due-to-a-drug-or-substance-high-altitude- periodic-breathing-csadue-to-a-medical-condition-other-than-cheyne-stokes/article/625213/ [cited 2019 Jul 27].

24. Javaheri S, Patel S. Opioids Cause Central and Complex Sleep Apnea in Humans and Reversal With Discontinuation: A Plea for Detoxification. J Clin Sleep Med. 2017;13(6):829-33. doi: 10.5664/ jcsm. 6628.

25. Alattar MA, Scharf SM. Opioid-associated central sleep apnea: a case series. Sleep Breath. 2009;13(2):201-6. doi: 10.1007/s11325008-0221-7.

26. Thorpy MJ. Classification of sleep disorders. Neurotherapeutics. 2012;9(4):687-701. doi: 10.1007/s13311-012-0145-6 27. Clinic M: Obstructive sleep apnea 2018 [Internet]. Available from: http://www.mayoclinic.org/diseases-conditions/obstructive-sleep-apnea/diagnosis- treatment/treatment/txc-20206034) [cited 2019 Jul 27].

28. Corlateanu A, Pylchenko S, Sircu V, Botnaru V. Predictors of daytime sleepiness in patients with obstructive sleep apnea. Pneumologia. 2015;64(4):21-5. doi: 10.13075/ijomeh.1896.00360.

29. Yagi H, Nakata S, Tsuge H, Yasuma F, Noda A, Morinaga M, et al. Morphological examination of upper airway in obstructive sleep apnea. Auris Nasus Larynx. 2009;36(4):444-9. doi: 10.1016/j. anl.2008.11.003.

30. Hukins C. Mallampati class is not useful in the clinical assessment of sleep clinic patients. J Clin Sleep Med. 2010;6(6):545-9.

31. Tan HL, Gozal D, Ramirez HM, Bandla HP, Kheirandish-Gozal L. Overnight polysomnography versus respiratory polygraphy in the diagnosis of pediatric obstructive sleep apnea. Sleep. 2014;37(2):25560. doi: $10.5665 /$ sleep. 3392 .

32. Tsara V, Amfilochiou A, Papagrigorakis MJ, Georgopoulos D, Liolios E. Guidelines for diagnosis and treatment of sleep-related breathing disorders in adults and children. Definition and classification of sleep related breathing disorders in adults: different types and indications for sleep studies (Part 1). Hippokratia. 2009;13(3):18791.

33. Neill AM, Angus SM, Sajkov D, McEvoy RD. Effects of sleep posture on upper airway stability in patients with obstructive sleep apnea. Am J Respir Crit Care Med. 1997;155(1):199- 204. doi: 10.1164/ajrccm.155.1.9001312.

34. Sullivan CE, Issa FG, Berthon-Jones M, Eves L. Reversal of obstructive sleep apnoea by continuous positive airway pressure applied through the nares. Lancet. 1981;1(8225):862-5. doi: 10.1016/s01406736(81)92140-1.

35. Center ASE: What is the Difference Between CPAP and BiPAP Therapy? [Internet]. Available from: http://www.alaskasleep.com/blog/ what-is-bipap-therapy-machine-bilevel- positive-airway-pressure [cited 2019 Jul 27].

36. Tregear S, Reston J, Schoelles K, Phillips B. Continuous positive airway pressure reduces risk of motor vehicle crash among drivers with obstructive sleep apnea: systematic review and meta-analysis. Sleep. 2010;33(10):1373-80. doi: 10.1093/sleep/33.10.1373.

37. Bradley TD, Floras JS. Obstructive sleep apnoea and its cardiovascular consequences. Lancet. 2009;373(9657):82-93. doi: 10.1016/ S0140-6736(08)61622-0.

38. Marin JM, Carrizo SJ, Vicente E, Agusti AG. Long-term cardiovascular outcomes in men with obstructive sleep apnoea-hypopnoea with or without treatment with continuous positive airway pressure: an observational study. Lancet. 2005;365(9464):1046-53. doi: 10.1016/S0140-6736(05)71141-7.

39. Spicuzza L, Caruso D, Di Maria G. Obstructive sleep apnoea syndrome and its management. Ther Adv Chronic Dis. 2015;6(5):27385. doi: $10.1177 / 2040622315590318$.

40. Bidarian-Moniri A, Nilsson M, Rasmusson L, Attia J, Ejnell $\mathrm{H}$. The effect of the prone sleeping position on obstructive sleep apnoea. Acta Otolaryngol. 2015;135(1):79-84. doi: 10.3109/00016489.2014.962183.

41. Eijsvogel MM, Ubbink R, Dekker J, Oppersma E, de Jongh FH, van der Palen J, et al. Sleep position trainer versus tennis ball 
technique in positional obstructive sleep apnea syndrome. J Clin Sleep Med. 2015;11(2):139-47. doi: 10.5664/jcsm. 4460.

42. Chan AS, Sutherland K, Schwab RJ, Zeng B, Petocz P, Lee RW, et al. The effect of mandibular advancement on upper airway structure in obstructive sleep apnoea. Thorax. 2010;65(8):726-32. doi: 10.1136/ thx.2009.131094.

43. HZZO: Medicinski proizvodi [Internet]. Available from: http:// www.hzzo.hr/zdravstveni- sustav-rh/medicinski-proizvodi/ [cited 2019 Jul 27].

44. Puhan MA, Suarez A, Lo Cascio C, Zahn A, Heitz M, Braendli O. Didgeridoo playing as alternative treatment for obstructive sleep apnoea syndrome: randomised controlled trial. BMJ. 2006;332(7536):266-70. doi:10.1136/bmj.38705.470590.55. 45. Hong SO, Chen YF, Jung J, Kwon YD, Liu SYC. Hypoglossal nerve stimulation for treatment of obstructive sleep apnea (OSA): a primer for oral and maxillofacial surgeons. Maxillofac Plast Reconstr Surg. 2017;39(1):27. doi: 10.1186/s40902-017-0126-0.

46. Tregear S, Reston J, Schoelles K, Phillips B. Obstructive sleep apnea and risk of motor vehicle crash: systematic review and meta-analysis. J Clin Sleep Med. 2009;5(6):573-81.

47. Schwartz AR, Patil SP, Laffan AM, Polotsky V, Schneider H, Smith PL. Obesity and obstructive sleep apnea: pathogenic mechanisms and therapeutic approaches. Proc Am Thorac Soc. 2008;5(2):185-92. doi: 10.1513/pats.200708-137MG.

48. Frye SS, Fernandez-Mendoza J, Calhoun SL, Gaines J, Sawyer $\mathrm{MD}, \mathrm{He} \mathrm{F}$, et al. Neurocognitive and behavioral functioning in adolescents with sleep-disordered breathing: a population-based, dual-energy X-ray absorptiometry study. Int J Obes (Lond). 2018;42(1):95-101. doi: 10.1038/ijo.2017.229.

49. Osorio RS, Gumb T, Pirraglia E, Varga AW, Lu SE, Lim J, et al. Sleep-disordered breathing advances cognitive decline in the elderly. Neurology. 2015;84(19):1964-71. doi: 10.1212/ WNL.0000000000001566.

50. Jordan AS, McSharry DG, Malhotra A. Adult obstructive sleep apnoea. Lancet. 2014;383(9918):736-47. doi: 10.1016/S01406736(13)60734-5.

51. Yaggi HK, Concato J, Kernan WN, Lichtman JH, Brass LM, Mohsenin V. Obstructive sleep apnea as a risk factor for stroke and death. N Engl J Med. 2005;353(19):2034-41. doi: 10.1056/NEJMoa043104.

52. Unnikrishnan D, Jun J, Polotsky V. Inflammation in sleep apnea: an update. Rev Endocr Metab Disord. 2015;16(1):25-34. doi: 10.1007/s11154-014-9304-x.

53. Narkiewicz K, Somers VK. The sympathetic nervous system and obstructive sleep apnea: implications for hypertension. J Hypertens. 1997;15(12 Pt 2):1613-9. doi: 10.1097/00004872-199715120-00062. 54. Tasali E, Mokhlesi B, Van Cauter E. Obstructive sleep apnea and type 2 diabetes: interacting epidemics. Chest. 2008;133(2):496-506. doi: 10.1378/chest.07-0828.

55. Pecotic R, Dodig IP, Valic M, Ivkovic N, Dogas Z. The evaluation of the Croatian version of the Epworth sleepiness scale and STOP questionnaire as screening tools for obstructive sleep apnea syndrome. Sleep Breath. 2012;16(3):793-802. doi:10.1007/s11325-011-0578-x. 56. Neill AM, Angus SM, Sajkov D, McEvoy RD. Effects of sleep posture on upper airway stability in patients with obstructive sleep apnea. Am J Respir Crit Care Med. 1997;155(1):199-204. doi: 10.1164/ ajrccm.155.1.9001312.

57. Cartwright RD. Effect of sleep position on sleep apnea severity. Sleep. 1984;7(2):110-4. doi: 10.1093/sleep/7.2.110
58. Cartwright RD, Lloyd S, Lilie J, Kravitz H. Sleep position training as treatment for sleep apnea syndrome: a preliminary study. Sleep. 1985;8(2):87-94. doi:10.1093/sleep/8.2.87

59. Oksenberg A, Silverberg DS. The effect of body posture on sleep-related breathing disorders: facts and therapeutic implications. Sleep Med Rev. 1998;2(3):139-62.

60. Oksenberg A, Khamaysi I, Silverberg DS, Tarasiuk A. Association of body position with severity of apneic events in patients with severe nonpositional obstructive sleep apnea. Chest. 2000;118(4):1018-24. doi: $10.1378 /$ chest.118.4.1018.

61. Cartwright RD, Diaz F, Lloyd S. The effects of sleep posture and sleep stage on apnea frequency. Sleep. 1991;14(4):351-3. doi: 10.1093/sleep/14.4.351.

62. Frank MH, Ravesloot MJ, van Maanen JP, Verhagen E, de Lange J, de Vries N. Positional OSA part 1: Towards a clinical classification system for position-dependent obstructive sleep apnoea. Sleep Breath. 2015;19(2):473-80. doi: 10.1007/s11325-014-1022-9.

63. Metersky ML, Castriotta RJ. The effect of polysomnography on sleep position: possible implications on the diagnosis of positional obstructive sleep apnea. Respiration. 1996;63(5):283-7. doi: $10.1159 / 000196561$.

64. Menon A, Kumar M. Influence of body position on severity of obstructive sleep apnea: a systematic review. ISRN Otolaryngol. 2013;2013:670381. doi: 10.1155/2013/670381.

65. Levendowski DJ, Seagraves S, Popovic D, Westbrook PR. Assessment of a neck-based treatment and monitoring device for positional obstructive sleep apnea. J Clin Sleep Med. 2014;10(8):863-71. doi: 10.5664/jcsm.3956.

66. Oksenberg A, Silverberg DS, Arons E, Radwan H. Positional vs nonpositional obstructive sleep apnea patients: anthropomorphic, nocturnal polysomnographic, and multiple sleep latency test data. Chest. 1997;112(3):629-39. doi:10.1378/chest.112.3.629.

67. Huang KT, Chin CH, Tseng CC, Chang HC, Chen YC, Wang $\mathrm{CC}$, i sur. The influence of obesity on different genders in patients with obstructive sleep apnea. The Scientific World Journal. 2014:2014:487215. doi:10.1155/2014/487215

68. Dancey DR, Hanly PJ, Soong C, Lee B, Shepard J, Jr., Hoffstein $\mathrm{V}$. Gender differences in sleep apnea: the role of neck circumference. Chest. 2003;123(5):1544-50. doi: 10.1378/chest.123.5.1544. 69. Wahner-Roedler DL, Olson EJ, Narayanan S, Sood R, Hanson AC, Loehrer LL, i sur. Gender-specific differences in a patient population with obstructive sleep apnea-hypopnea syndrome. Gend Med. 2007;4(4):329-38.

70. Cairns A, Poulos G, Bogan R. Sex differences in sleep apnea predictors and outcomes from home sleep apnea testing. Nat Sci Sleep. 2016;8:197-205. doi: 10.2147/NSS.S101186.

71. Heinzer R, Vat S, Marques-Vidal P, Marti-Soler H, Andries $\mathrm{D}$, Tobback N, i sur. Prevalence of sleep-disordered breathing in the general population: the HypnoLaus study. Lancet Respir Med. 2015;3(4):310-8. doi: 10.1016/S2213-2600(15)00043-0.

72. Drager LF, Togeiro SM, Polotsky VY, Lorenzi-Filho G. Obstructive sleep apnea: a cardiometabolic risk in obesity and the metabolic syndrome. J Am Coll Cardiol. 2013;62(7):569-76. doi: 10.1016/j. jacc.2013.05.045.

73. Mador MJ, Kufel TJ, Magalang UJ, Rajesh SK, Watwe V, Grant BJ. Prevalence of positional sleep apnea in patients undergoing polysomnography. Chest. 2005;128(4):2130-7. doi:10.1378/ chest.128.4.2130 